\title{
FORUM
}

\section{INTEGRAL ECONOMICS AND THE EXPLORATION OF INDIGENOUS KNOWLEDGE}

\author{
SOMNATH GHOSAL ${ }^{1}$
}

\begin{abstract}
The ever-increasing pressures on tropical forests due to the increasing population of socio-economically deprived communities dwelling in forest fringe areas are not only a matter of ecological concern, but also affect the sustainable livelihoods of these communities. Alternative sources of income are urgently needed for these communities. Forest is the principal natural resource for the Purulia, Bankura and West Midnapur districts of West Bengal, India. More sustainable harvesting of forest products, particularly Non-Timber Forest Products (NTFPs) and the production of value-added products would therefore be the best possible way to improve the existing economic conditions of deprived forest fringe communities and save native forest biodiversity for the future.
\end{abstract}

KEYWORDS NTFPS, economy, tribal, forest management, knowledge

\section{INTRODUCTION}

NTFPs have been defined as "... all biological materials, other than timber, which are extracted from forests for human use" (NTFP Exchange Programme Website 2007). They include fruits, resins, gums, herbal plants, roots, honey and wood that is not used for timber (for example, firewood). The type, number and nature of NTFPs vary from one geographical area to another based on the local geo-physical conditions. Due to the increasing economic value of NTFPs, people from different fields (such as environmentalists, economists and sociologists) are becoming more interested in these products. The current estimated total world trade value of NTFPs is approximately US $\$ 1.1$ billion (Wilkinson and Elevitch, 2000) and the market has grown by nearly $20 \%$ annually over the last twenty years (Hammett, 1999).

1 Somnath Ghosal is assistant professor at the Centre for Studies in Social Sciences, Calcutta; e-mail: ghosal.somnath@rediffmail.com 
NTFPs have the potential to be a means of generating forest-based economic development. Sustainable management of forest products other than timber can create full or part-time employment opportunities for people living in or near forest areas. As the sustainable management of these products can increase opportunities for employment, governments (particularly those of the Global South) are placing special emphasis on promoting it (Corbridge and Kumar, 2002). In 1998, the Centre for International Forestry Research (CIFOR) began a major piece of global-scale research to provide information about NTFPs and their relations to land use and local livelihood strategies (http://www.cifor.cgiar.org/; accessed $7^{\text {th }}$ of October 2007). Presently, this organization is focusing on promoting the commercialization of NTFPs in an environmentally-friendly manner for the economic development of forest dwellers.

Tribal forest communities are the main collectors of NTFPs in India. This is labor intensive work and about half of the income of tribal people who live in or around forest areas comes from NTFPs (Singh and Ardey, 2003). Around 3000 types of NTFPs are found across India (Non-Timber Forest Products Exchange Program 2007). The socio-economic value of NTFPs can contribute to keeping intact the ecological balance of Indian forests (Yadav and Roy, 1991). In the east of India (where a high proportion of forest dwellers still live), the main source of NTFPs is open dry-deciduous forest cover (including protected and unclassed state forests ${ }^{2}$ ). Mainly leaves, flowers and seeds are collected from this region.

The theme of this paper; therefore, is the conservation of open drydeciduous forest covers of the Purulia, Bankura and West Midnapur districts of West Bengal, India, through promoting the socio-economic status of forest villagers. The use of Non-Timber Forest Products (NTFPs) is manifold in indigenous forest communities. The systematic and sustainable harvesting of NTFPs could improve the standard of living of forest dwellers and play an important role in the conservation of forest ecosystems.

The research described in this paper was conducted to address the following questions:

1. What types of NTFPs are available in the protected forests or unclassed state forests of West Bengal where a high number of socio-economically deprived communities are located?

2 Unclassed State Forest - "An area recorded as forest but not included in reserved or protected forest category. Ownership status of such forests varies from state to state.” Source: State Forest Report, West Bengal 2003-2004, p. 4. 
2. How are forest livelihoods and culture dependent on locally-available NTFPs and how have traditional knowledge and practices regarding the use of NTFPs changed in recent years?

3. What is the status of collection and conservation of NTFPs for commercial as well as household purposes at the community level?

In order to address the above questions, a comparative study was carried out on the marketing of NTFPs by formal and informal (legal and illegal) sectors in the dry-deciduous forest areas of West Bengal. It is expected that the results of this study might form the basis for policy recommendations regarding NTFP harvesting and management in eastern India.

\section{IMPORTANCE OF NTFPS FROM THE PERSPECTIVE OF THE GLOBAL AND REGIONAL ECONOMY}

A large amount of research has already been completed about the protection and development of forest and forest products from all over the world, focusing on different aspects of forest livelihoods (Bürgi, 1999; Jodha, 1990; Byron and Arnold, 1999; Chun-Lin et al., 1999; Torras, 2000). Out of a total of 800 million hectares of protected (or reserved) forest areas, most are located in developing countries within the tropics (Gunatilake, 1998). These tropical forest areas "...may be among the areas containing the greatest wealth of 'non-market'benefits” in the world (Torras, 2000, p. 285). A considerable area of this tropical forest has disappeared within the last few decades. Unplanned collection of (precious) timber for several purposes is the main reason for the massive deforestation in the tropics (Mendelsohn, 1994; Torras, 2000).

Like other tropical countries in South Asia, the same thing has been happening in Indian woodlands. In a seminal study of dry land plain areas in several Indian states, Jodha (1990) found that the area of common pool land available to villagers as a source of forest products had declined by margins ranging from $31 \%$ to $55 \%$ in the 30 years after 1951 (Jodha, 1990, cited in Byron and Arnold, 1999, p. 795). Although the deforestation of tropical forests has been happening at a fast rate for economic development, it is not clear to environmentalists or economists how much deforestation has contributed to social progress to date. How much clearance of tropical forests should be allowed for the sake of different socio-economic activities is a vital question for contemporary environmentalists as well as economists.

Bürgi (1999) has divided the history of forest use and management into three phases: the 'period of traditional multiple use' (until the mid $19^{\text {th }}$ 
century); the 'period of primacy of timber production' (from the mid $19^{\text {th }}$ to mid $20^{\text {th }}$ century) and the 'period of modern multi-impact management' (from the mid $20^{\text {th }}$ century to date). In his analysis of these three phases, Bürgi focused on human-forest relationships in Swiss lowland forest areas. How human needs which are satisfied by local forests affect the forest ecosystem was the main theme of his research. Human needs include timber as well as NTFPs. The demand and collection of timber and NTFPs varied from one phase to another (Bürgi, 1999). During the first phase, the value of timber and NTFPs were similar; in the middle phase the value of NTFPs were underestimated compared to timber products and in the third phase (presently) NTFPs are considered to be more valuable than the timber products from the perspective of forest ecosystem management as well as their ability to economically support forest dwellers. Changes in human needs are the main causes of this shift.

During the implementation of an FAO/UNDP project in the South Pacific region, Olsson (1991) focused on the multipurpose uses of NTFPs by forest dwellers living in the Republic of Vanuatu and how the proper harvesting of NTFPs can save the forest ecosystem in the long run. There are several sociocultural practices undertaken by forest dwellers to protect plant species that produce NTFPs. Ultimately, these practices help to protect the forest cover of the country. The development of forest areas, the sustainable uses of NTFPs and the implementation of traditional practices of forest product management were the focus of this research.

Before discussing the relationships between forest and forest people, it is necessary to identify who the forest people are, to what extent they are related to the forest, and what their location is, in the context of the forest. There are three main reasons why tropical forest people depend on forest products. First of all, collecting forest products may represent an 'attractive' job; secondly, it could be their only option and the only way to fight poverty; and finally, forest people may undertake these activities because of 'strong cultural or spiritual reasons' (Byron and Arnold, 1999, p. 789-790). NTFPs are collected by forest dwellers, living within or outside Indian forests, for household as well as commercial purposes.

It is, however, quite difficult to analyze the importance of NTFPs for forest livelihoods from a general perspective. The relationship between forest people and NTFPs varies with the nature of the forest, the forest products and the adjacent socio-physical surroundings. It also differs with “...the wide variation in needs and use of forest outputs between richer and poorer within a [forest] community, and within a household between men and women, and even between age groups" (Byron and Arnold, 1999, p. 796). 
Byron and Arnold's (1999) extensive research on the importance of NTFPs on forest peoples' cultural, social and economic lives in tropical forests sought to produce data and information on the contemporary features of demand, supply and use of NTFPs in supporting forest people. They also performed a detailed study about the identification, location and dependence of forest people living in or around tropical forests and the relationship between tropical forests and how the forest people change them in accordance with the adjoining geo-physical environment. The cultural value of NTFPs is something that aboriginal people have great regard for, but is often neglected by outsiders (Turner, 2001). The present overexploitation and lack of knowledge about the appropriate uses of NTFPs by outsiders have hampered fostering the sustainability of native forest ecosystems.

Indigenous forest dwellers have often developed their own methods for the sustainable harvesting of NTFPs. New methodologies should consider indigenous knowledge carefully. It might be useful if traditional knowledge and modern scientific methods are combined, particularly when NTFPs are harvested for commercial purposes (Pfund and Robinson, 2005).

Any change in the extent and quality of the forest, or in access to traditional forest areas, is likely to be very disruptive for traditional use and activity patterns. Some populations (e.g., in parts of the Amazon basin) have managed to retain predominantly subsistence and self-reliant ways of life. Most, however, are increasingly affected by exposure to market forces. Where this is the case they tend to be highly dependent on middlemen for access to outside markets for sale of their products, and for supplies of outside goods (Byron and Arnold, 1999, p. 797).

During his work in Indonesian forest areas, Kerr (1991) focused on the traditional uses of NTFPs for the making of handicraft goods by forest people in Indonesia and how these handicraft products can improve the economic conditions of forest people. Marketing of NTFP-based handicraft products helps to solve unemployment problems among forest dwellers and to meet their needs without overexploiting the forest resource base.

To protect tropical forests, all the products produced in tropical forests should be identified properly and then their 'relative' values should be calculated. Based on these relative values, approaches should be taken for the preservation and development of individual forests (Myers, 1988). It is, however, quite difficult to use an analogous policy for the Amazon, Congo or south-east Asian tropical forests because of the diverse nature of forests and forest-people relationships. As a result, micro level research is becoming more important for intensive study at the grassroots level for the implementation of existing policy and further planning. 
Internationally, there has been an increase in both academic and nonacademic research on NTFPs and forest livelihoods from the perspective of historical geography which includes the study of colonial forestry, indigenous knowledge, developmental issues, political ecology and environment and society. However, most of the research has been done based on specific issues. For example, Torras (2000), Mendelsohn (1994) and Peters et al. (1989) focused only on the commercial importance of forest and forest products, whereas, Belcher et al. (2005) and Byron and Arnold (1999) discussed the importance of NTFPs in terms of forest management through the diminution of rural poverty. While Turner (2001), Emery (1998), Steinberg (1998) and Pulido and Caballero (2006) have concentrated on socio-cultural life based on NTFPs, Pfund and Robinson (2005), Salisbury (2002) and Putz et al. (2001) were more concerned about the role of sustainable harvesting of NTFPs in preserving the forest ecosystem.

Less attention has been paid to the more holistic perspective about NTFPs and forest livelihoods. Research on NTFPs from a particular standpoint may hinder the construction of a comprehensive policy for managing forest cover and neglect the issue of the need to socio-economically deprived forest communities. For the construction of a comprehensive plan about NTFPs and forest livelihoods, it is important to conduct research that integrates all the related perspectives.

\section{THE STUDY AREA AND THE METHODOLOGIES USED FOR DATA COLLECTION AND ANALYSIS}

Most of the previous research on NTFP and forest livelihoods in India and West Bengal has been conducted in reserved forests of tropical and temperate regions (Chandrasekharan, 1998; Mallik, 2000; Corbridge and Kumar, 2002; Mahapatra and Tewari, 2005). However, a significant amount of NTFPs are harvested from open (protected) forests as well. There are hardly any government records about many of these products (Department of Forest, 2004 and 2005; WBFDC, 2006). Therefore, this research was designed to focus on forest livelihoods in the tropical dry-deciduous forests of West Bengal and the extent to which forest people are exploited by middlemen or mobile agents. In the open dry-deciduous forest areas of south-western West Bengal, many forest dwellers have low socio-economic status and a number of NTFPs are marketed through informal channels by middlemen and mobile agents. The area selected for study, which includes the districts of Purulia, Bankura and 
West Midnapur, is therefore an ideal place to conduct such research and to address existing gaps in the NTFP literature.

Due to the lack of arable land and limitations on agricultural activities, the forest people of these three districts (Bankura, Purulia and West Midnapur) usually go to the districts of Bardhaman, Birbhum, Nadia and Hooghly as agricultural wage laborers during the monsoon (June - August) and late autumn (October - November) seasons when the collection of NTFPs is less widely practiced. For the rest of the year, their main occupation is the collection of NTFPs from the local forest. The drought prone areas of the districts of Purulia, Bankura and West Midnapur are quite famous for their unique tropical dry-deciduous forests which cover only 0.430 million hectares of India in total (Department of Forest, 2005).

The typical forest type and the long-standing forest-people relationships of the area are interesting topics for natural as well as social scientists (Mahapatra and Tewari, 2005). The lateritic zone, popularly known as the 'Rarh Bhumi', covers the Purulia, Bankura and West Midnapur districts and parts of the Birbhum district of West Bengal. The hot, moist sub-humid to very hot dry sub-humid climate, the nature of the soil (mainly red lateritic soil) and the physiographic landscape are the main reasons why this special (typical) type of forest is concentrated in these three districts.

For this research, the collection of qualitative and quantitative data and information from both primary and secondary sources received equal priority. To analyze primary and secondary data, qualitative as well as quantitative methodologies were used simultaneously. This research started with detailed archival work at the British Library in London. Archival research provided data and information about NTFPs and the forest livelihoods of pre-colonial and colonial Bengal and presented the historical context. Although there are no official records or documents about pre-colonial forest livelihoods and the effects of NTFPs on them in the Presidency of Bengal, the books, articles and correspondence of different forest officers of the British colonial government in India (such as Ribbentrop, 1900; Gibson, 1856 and Brandis, 1864) were found to be useful.

To analyze the post-colonial features of forest and NTFPs of West Bengal, the State Government's annual Forest Reports, the West Bengal Forest Development Corporation (WBFDC) annual reports $(1990-2007)$ and the West Bengal Tribal Development Cooperative Corporation Ltd. (WBTDCC) annual reports $(1990-2005)$ were examined. Only a limited amount of relevant previous research has been done on NTFPs and forest livelihoods in east Indian states (by Malhotra, 1993; Mitchell et al. 1999; Mahapatra et al., 2005; Corbridge and Kumar, 2002; Corbridge et al., 2004; Jewitt, 2002). 
Therefore, during the analysis of NTFPs and forest livelihoods of the research area, in addition to the annual reports of different government organizations, previous project reports by organizations such as the Indian Institute of Biosocial Research and Development (IBRAD) and the National Afforestation and Eco-Development Board (NAEB) were consulted. Books and articles on NTFPs and forest livelihoods in developing countries, web maps, web journals and newspaper articles were referred to as sources of secondary data and information.

To identify villages and households for semi-structured interviews, different types of maps were used. To get a clear view of the socio-physical features of the sampled villages, land-use and land-cover maps (including forest cover), hydro-geomorphological maps, drainage and water-body maps and soil maps were referred to. For this purpose, offices such as the State Remote Sensing Centre (Department of Science and Technology, Government of West Bengal), the National Bureau of Soil Survey and Land Use Planning (NBSSLUP), All India Soil Survey and Land Use (AISS) and Forest Survey of India (FSI), Kolkata were contacted. Topographical maps of the Survey of India at a scale of $1: 25,000 ; 1: 50,000$ and 1:250,000 were used during fieldwork. The National Atlas and Thematic Mapping Organization (NATMO) published a 'District Planning Map' of the Bankura, Purulia and Midnapur districts in 1990s using remote sensing technologies. All these maps were made at a scale of 1:250,000 and these maps were also used during the period of fieldwork.

For the collection of primary or empirical data and information, mainly qualitative methods were used. These included semi-structured interviews, focus group discussions and elite interviews. Semi-structured interviews were arranged with forest dwellers and NGO staff who are involved with NTFPs harvesting in dry-deciduous forest area in the State. To get data and information from forest officers, different types of interviews were arranged. Questionnaires were used for the household survey with forest dwellers to obtain qualitative as well as quantitative data. In addition to these methodologies, participant and direct observation as well as participatory appraisal were undertaken to collect information on the collection, storage and marketing of NTFPs at the grassroots level. They were also helpful for analyzing the impacts of NTFPs on forest livelihoods. Primary data and information were collected from the three case study districts of West Bengal where the greatest amounts of open and protected forests are found and the dependence of forest dwellers on NTFPs is also noticeable.

During the semi-structured interviews and participant-observations, the presence of elderly and young individuals created some ethical issues. The researcher was cautious in this regard. The researcher always maintained 
confidentiality according to participants' wishes concerning data collection and handling. Any incident or phenomenon that could prove harmful to respondents was not included in the research findings. All the data related to age, sex, community background, economic status and the ethnic origin of respondents were handled in a careful manner. The notions of ecology, ecosystem and environment amongst the research communities varied considerably compared to the knowledge of Forest Department staff. During the time of data analysis, confidentiality regarding these topics has been maintained.

As the activities of forest fringe dwellers are restricted in reserved forests or sanctuaries, disturbance in these areas is also limited. On the other hand, in the south-western part of West Bengal (including the districts of Purulia, Bankura and West Midnapur) where protected forests are concentrated, forest dwellers or tribal are allowed to collect forest products for their livelihoods. The condition of the protected forests of this area is steadily degrading.

\section{EXPLORATION OF INDIGENOUS KNOWLEDGE FOR A NTFP-BASED ECONOMY}

Indigenous forest people have lived for a long time in the south-western part of West Bengal and have been dependent, to a lesser or greater extent, on forest resources (Das, 2005). They are born and brought up in the forest and the impact of the forest on their cultural, social and economic life is quite noticeable (Yadav and Roy, 1991; Chowdhuri et al., 1992; Malhotra, 1998). From dawn to dusk, forest villagers use NTFPs for several household purposes. Therefore, their social life is often structured by the availability of forest resources. The more that can be learned about the uses of NTFPs by these villagers, the more appropriate the policies developed by the state Forest Department are likely to be. NTFPs are used here as food, fodder, medicine, decoration, household necessities and for other purposes (Roy, 2003; Malhotra et al., 1992 and 1998). The use of numerous plant species for medicinal purposes is widespread amongst forest dwellers. Normally, if forest villagers suffer any physical ailment, their first port of call is the Vaidya (a local doctor who prepares Ayurvedic medicine using a wide range of plant species) rather than a qualified (allopathic) doctor.

During fieldwork, it was noticed that the relationships between interior forest villagers and the forest is stronger than that of their counterparts living in forest fringe villages. The socio-cultural linkages between forest fringe dwellers and local areas have declined in recent years. This seems to be 
true for all three Districts of the study area. The socio-cultural features of a community are often determined by the surrounding environment (Chowdhuri, 1992; Malhotra et al., 1998). The culture of forest communities in the southwestern part of West Bengal is no exception. The available forest resources have moulded the cultural life of these forest communities for years. The purpose and use of NTFPs in these forest communities is sometimes distinctly different to the normal uses of NTFPs. For example, outside the forest, Sal leaves are mainly used for plate making, whereas in the social life of forest villages, they have many other uses.

Like Sal, Mahua, Karanj, Kusum and some other plant species have numerous uses in forest social life. These plants are widely worshipped. A culture of protecting these particular plant species has grown up among some of the forest communities, particularly among tribals and they try to follow it at all costs. Forest villagers do not start to collect newly sprouted leaves, flowers or fruits of these species until they have worshipped. This is done to maintain a future supply of these plant species. In the past, some forest areas used to be considered sacred areas from where the collection of any type of forest product was prohibited. Forest inhabitants believe that the God of the forest might live in these areas and they should not be disturbed or annoyed (Bhakat and Pandit, 2003; Gadgil and Vartak, 1975). Forests were also protected as a means of sustaining forest livelihoods and protecting villagers' livestock. Normally, if villagers are in need of medicinal plants, they collect them from these sacred areas. The villagers believe that forest Gods have bestowed their blessings on these plants species. Therefore, these areas have largely been protected.

Graphs 1, 2 and 3 display the percentage of collected NTFPs used for several purposes by forest fringe villagers. In all three Districts, the majority of types of NTFP are used as food, followed by their use in medicine and as industrial raw materials. As the number and type of NTFPs is higher in Purulia and Bankura districts than in the West Midnapur district, many NTFPs are collected for miscellaneous purposes in these two Districts. The purpose of collection is often for household needs as well as commercial requirements in the Purulia and Bankura districts. In the West Midnapur district, however, the percentage of NTFPs collected for commercial purpose $(25.96 \%)$ is higher than for the other two Districts. In the West Midnapur district, more of the NTFPs are collected for commercial purposes than to satisfy household needs. 
Graph 1 Percentage of the total number of NTFPs collected for different purposes in Arsha range of Purulia district

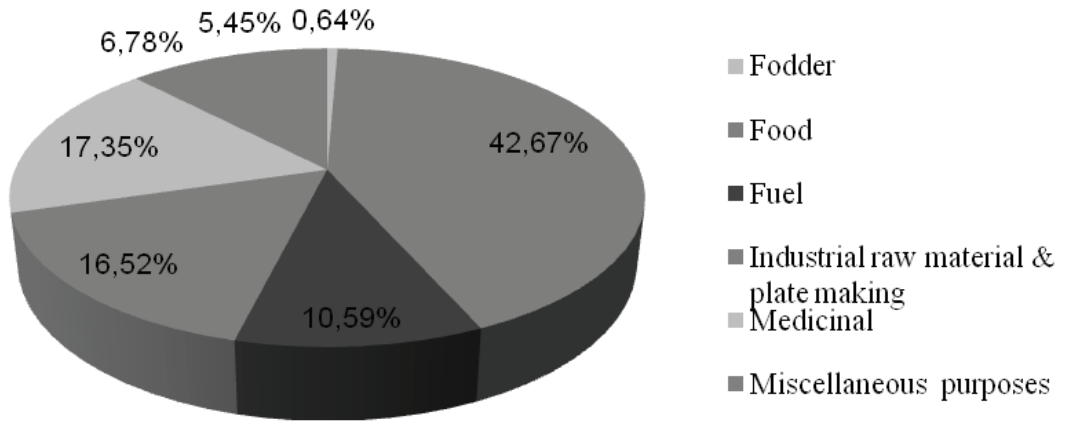

Graph 2 Percentage of the total number of NTFPs collected fordifferent purposes in Ranibandh range of Bankura district

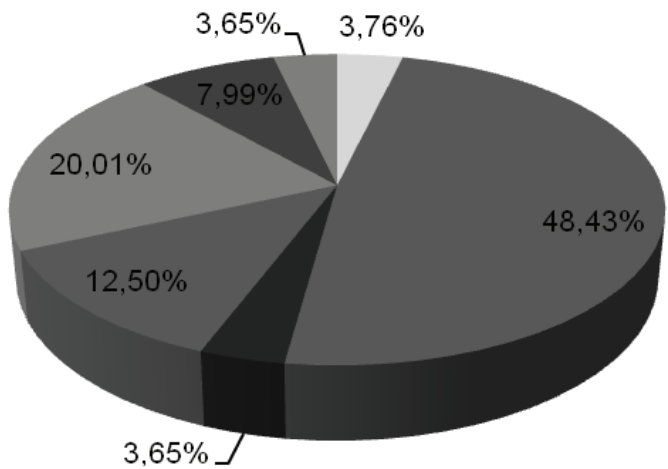

Fodder

- Food

- Fuel

- Industrial raw material \& plate making

- Miscellaneous purposes

Therefore, the economic importance of NTFPs in forest livelihoods can be broadly divided into two categories - a) NTFPs for household needs, for which forest villagers do not pay any money (but if they purchased those products from the market then they would have to spend money on them); and, b) NTFPs for marketing or commercial purposes, from which villagers earn money which they use for different purposes (Graph 4). 
Graph 3: Percentage of the total number of NTFPs collected for different purposes in Jamboni range of West Midnapur district

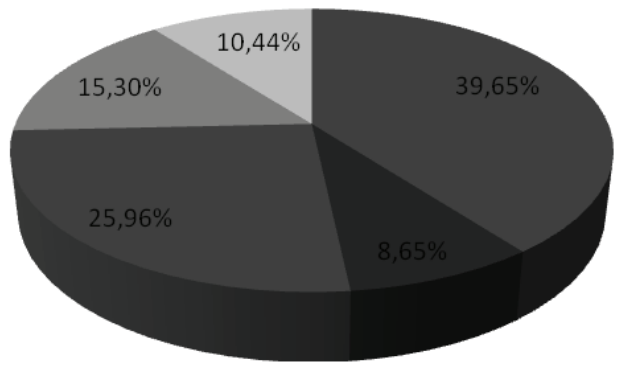

- Food

- Fuel

- Industrial raw material \& plate making

- Medicinal

$\square$ Miscellaneous purposes

Graph 4: Percentage of collected NTFPs sold in different ways in Purulia, Bankura and West Midnapur districts

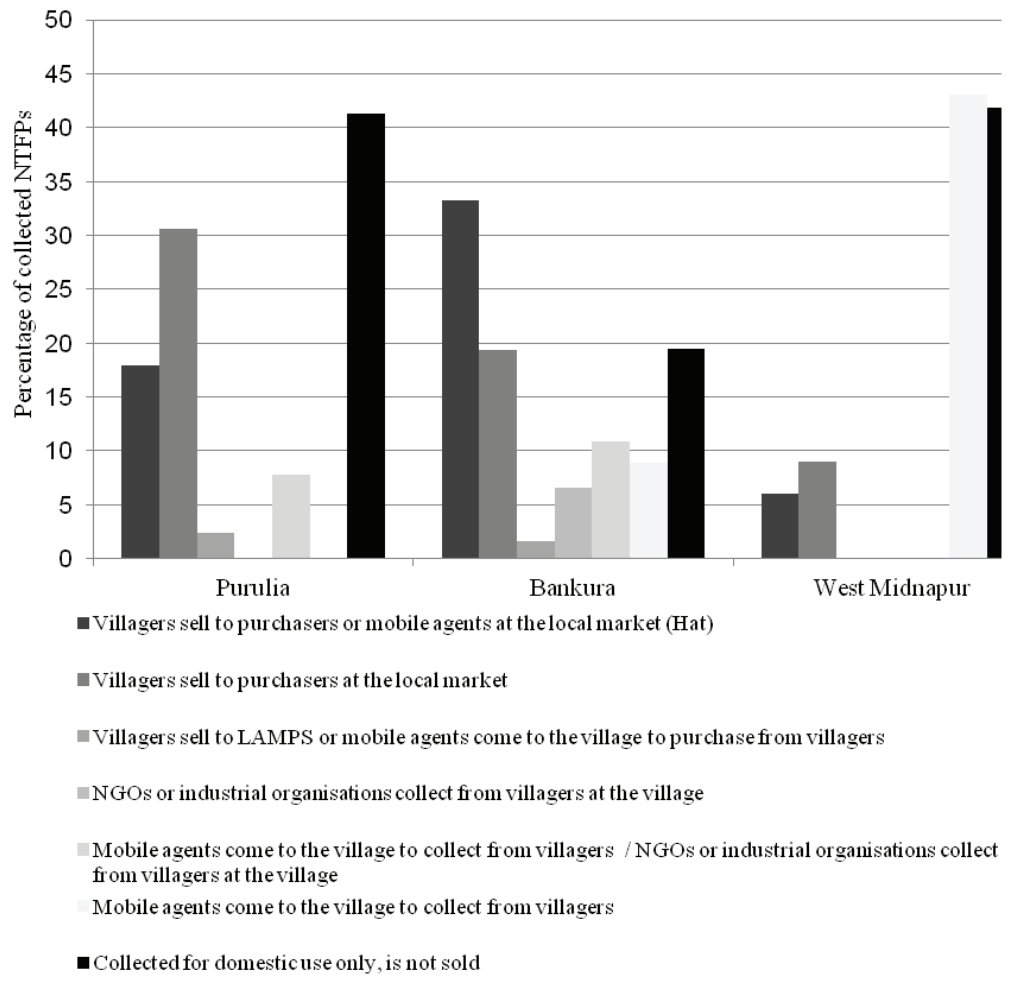


Apart from the above-listed uses with direct economic importance, NTFPs are also used to generate value-added products. Unprocessed NTFPs are sometimes awarded less commercial and domestic importance when compared to value-added products. This is because the use value of the secondary (manufactured) products is greater. For example, some bark, leaves and flowers, when collected from the forest areas, are sold for a very low price, yet when the same products are transformed into value-added products, the prices rise significantly. Other estimates suggest that up to 35 per cent of the income of tribal households in India comes from the collection of unprocessed NTFPs... Small scale forest-based enterprises, many of them based on NTFPs, (can) provide up to 50 per cent of income for 20 to 30 per cent of the rural labor force in India (Tewari and Campbell, 1995, p. 54).

In the dry-deciduous forest area of Purulia, Bankura and West Midnapur districts, Sal leaf collection is a popular job for most forest households. Sal leaves are stitched by hand to produce $\mathrm{Sal}$ plates, which are popularly known as sia-pata (hand stitched plates). The price of such plates is quite low. However, after the introduction of Sal plate making machines, the quality of plates has become much better and these are now even used in popular hotels and restaurants in Indian cities.

Since the machine-made plates are expensive (due to the use of electricity, and other costs) when compared to handmade ones, rural people do not normally use such plates. Local demand for machine-made plates is therefore low, hence local agents or businessmen tend to purchase these plates and send them to urban markets. These agents often try to pay forest dwellers as little as possible. This is why forest dwellers are not interested in producing such plates. Each stage, from Sal leaf to sia-pata (and to machine made plate) involves value-addition and the maximum value-addition takes place in the process of making $\mathrm{Sal}$ plates. Unfortunately the traders and commercial entrepreneurs dominate in this last stage of value addition (Development and Planning Department, Government of West Bengal, 2007, p. 56).

Although some forest dwellers have obtained plate-making machines from the state Forest Department, many prefer to produce hand-stitched plates which are cheap, are in high demand in the region and can be sold directly to purchasers at local markets. As a result, the likelihood of being exploited using this marketing system is less. If a well-organized marketing system for mechanized Sal plates were to be developed then forest dwellers might be more interested in producing such plates as they fetch more profit than the hand-stitched plates.

Mahua (Madhuca indica) flowers are used to make liquor, for eating as a vegetable and the seeds (Kachra) are used to produce oil. The oil has a range 
of uses - it can be used as an edible oil and massage oil - but there is no good marketing system for such value-added products. The liquor produced from Mahua flowers is very popular among [tribal] forest dwellers. The same liquor could be manufactured more scientifically and systematically to enhance its marketability. During the making of oil from the Mahua flower, a type of wax is also produced that is also used for several household purposes (such as in mosquito coils, pain-relieving balms, etc.) by tribal forest dwellers. However, people from outside the forest area do not know about the uses of such products. Forest dwellers, unfortunately, have no outlet for selling these value-added products at a good price. In order to encourage better management of the dry-deciduous forest areas of this region and to reduce forest dwellers' dependence on timber products for subsistence purposes, initiatives are urgently needed to support the manufacturing and marketing of value-added products in the districts of Purulia, Bankura and West Midnapur.

Another important NTFP which is collected on a regular basis in Bankura district is Babui grass which is used for rope making. Such types of rope have multiple uses. They are value-added products which command a much higher price than unprocessed Babui grass. The WBTDCC collects Babui grass occasionally but they do not have adequate storage facilities for this product, unlike with Kendu leaves or Sal seeds. Therefore, most Babui grass sales are undertaken by local agents or middlemen and because of this, the actual collector often receives a very low price: “...both male and female members of tribal families of south Bankura are efficient in making Babui rope which has steady demand in the markets within the State, as well as in other states like Uttar Pradesh and Rajasthan. But in absence of local market facilities, the middleman dominates which leads to deprivation of the growers of competitive price" (Development and Planning Department, Government of West Bengal, 2007, p. 56).

The same problem occurs with respect to the Eucalyptus oil business. According to the Harinaganj villagers in the Jamboni range of West Midnapur district ${ }^{3}$, "there are lots of Eucalyptus trees in the local forest and their leaves are used to produce oil. This oil is used for several purposes including industrial raw materials for cosmetic products, but there is no proper marketing system developed to sell such oil so nobody is interested in collecting Eucalyptus leaves. At present, there is no industrial demand for the collection of this leaffor oil production".

3 Group discussion, $2^{\text {nd }}$ of December 2008, the medium of conversation was Bengali 
Graph 5: Percentage of the total amount of collected NTFPs in Purulia, Bankura and West Midnapur districts

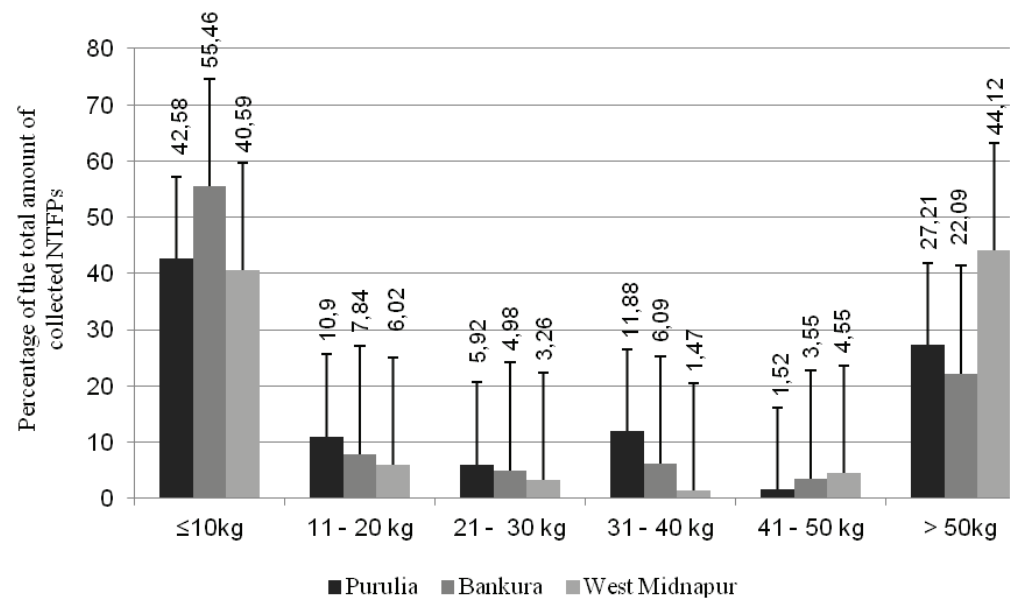

Graph 5 shows that most NTFPs are collected in quantities of less than $10 \mathrm{~kg}$ for an average household per year. This is true for all three Districts. This shows that the quantity of NTFPs collected is in most cases is quite low. The number of NTFPs collected tends to decrease as the quantity collected increases. There is therefore an inverse relationship between the number and quantity of NTFPs (fewer NTFPs are collected in larger amounts). Again, there are some NTFPs (such as firewood, fodder, leaves for use as vegetables, Sal leaves, etc.) which are collected on a regular basis throughout the year. The total amount of these products collected is more than $50 \mathrm{~kg}$ per year per household.

During fieldwork it was noticed that with increases in distances from the forest the use of value-added NTFPs also increases, which supports the hypothesis of the 'distance decay model' (Taylor, 1971) and Von Thunen's findings on the effects of distance and transaction costs. In remote villages, only hand-stitched Sal plates (sia-pata), mats (produced from Date leaves) and bidi (cigarettes) are manufactured as value-added or secondary products. A few types of oil and liquor are also produced as secondary products from NTFPs in remote villages, but they are hardly ever marketed. In contrast, people living close to market areas or in towns purchase raw NTFPs from mobile agents or middlemen and manufacture different types of value-added products. They also sell them locally as well as sending those secondary products to urban 
areas for further processing and marketing. This is also true for most of the medicinal plants harvested in the Purulia and Bankura districts.

Table 1. The ten most important NTFPs in the Arsha range of the Purulia district (ranked by forest villagers)

\begin{tabular}{|c|c|c|c|c|c|c|c|c|}
\hline SI No & $\begin{array}{l}\text { Name of } \\
\text { NTFPs }\end{array}$ & Availability & $\begin{array}{c}\text { Quantity } \\
\text { of product } \\
\text { collected } \\
\text { per year/ } \\
\text { Household }\end{array}$ & $\begin{array}{l}\text { Commercial } \\
\text { importance }\end{array}$ & $\begin{array}{l}\text { Household } \\
\text { importance }\end{array}$ & $\begin{array}{l}\text { Monetary } \\
\text { value of the } \\
\text { product }\end{array}$ & $\begin{array}{l}\text { Multiple } \\
\text { uses of the } \\
\text { product }\end{array}$ & *Grade \\
\hline 1 & Firewood & Whole year & $>3,000 \mathrm{~kg}$ & $\checkmark$ & $\checkmark$ & Rs. $2 / \mathrm{kg}$ & $\checkmark$ & 5 \\
\hline 2 & Sal (leaf) & 8 months & $\begin{array}{c}24,000 \\
\text { plates }\end{array}$ & $\sqrt{ }$ & $\checkmark$ & $\begin{array}{l}\text { Rs. } 50 / 1,000 \\
\text { plates }\end{array}$ & $\checkmark$ & 5 \\
\hline 3 & Bel (fruit) & 2 months & $30 \mathrm{~kg}$ & $\checkmark$ & $\checkmark$ & Rs. $2 / \mathrm{kg}$ & $\checkmark$ & 5 \\
\hline 4 & $\begin{array}{c}\text { Haritaki } \\
\text { (fruit) }\end{array}$ & 3 months & $15 \mathrm{~kg}$ & $\checkmark$ & $\checkmark$ & Rs. $2 / \mathrm{kg}$ & $\checkmark$ & 5 \\
\hline 5 & Amla (fruit) & 2 months & $10 \mathrm{~kg}$ & $\sqrt{ }$ & $\checkmark$ & Rs. $3 / \mathrm{kg}$ & $\sqrt{ }$ & 5 \\
\hline 6 & Kend (leaf) & 2 months & $\begin{array}{l}15 \text { Chata } \\
\text { (Bundle) }\end{array}$ & $\checkmark$ & $\checkmark$ & $\begin{array}{l}\text { Rs. 25/ } \\
\text { Chata }\end{array}$ & & 4 \\
\hline 7 & Harla (bark) & 2 months & $20 \mathrm{~kg}$ & $\checkmark$ & & Rs. $15 / \mathrm{kg}$ & & 4 \\
\hline 8 & Jam (fruit) & 1 months & $10 \mathrm{~kg}$ & $\sqrt{ }$ & $\checkmark$ & Rs. $5 / \mathrm{kg}$ & & 4 \\
\hline 9 & $\begin{array}{l}\text { Kham-alu } \\
\text { (tuber root) }\end{array}$ & 2 months & $20 \mathrm{~kg}$ & & $\sqrt{ }$ & & & 3 \\
\hline 10 & $\begin{array}{c}\text { Genthi-alu } \\
\text { (tuber root) }\end{array}$ & 2 months & $15 \mathrm{~kg}$ & & $\checkmark$ & & & 3 \\
\hline
\end{tabular}

Differences in the purpose for NTFP harvesting between inter-district and intra-district areas are quite apparent (Tab. 1, 2 and 3). Based on: 1) the availability of the product in a year; 2) their monetary value; 3) the amount collected; 4) their usability; and 4) their commercial and domestic importance, the ten most important NTFPs from these three districts have been ranked.

The rank of NTFPs in the comparison varies from one area to another in the same District as well as from one District to another. These rankings were derived from discussions with forest dwellers during participation and direct observation and using participatory appraisal techniques. With respect to the importance of NTFPs in the household economy, villagers from the Katiam village in the Ranibandh range of the Bankura district" mentioned that: "For our needs we have to save this forest. Those plants which produce more than one NTFP or are important for timber as well as NTFP, those plants we have to protect anyhow. Like from Mahua or Mahul (Madhuca indica) tree, we

4 Group discussion, 11th of November, 2008, the medium of conversation was Bengali and Santhali) 
get flower and fruit and from fruit we get seed-all are useful for different purposes. We collect all these products for domestic as well as commercial purposes. Therefore, we have to protect Mahua tree at any cost. Same for Sal, Piyal.".

Table 2. The ten most important NTFPs in the Ranibandh range of the Bankura district (ranked by forest villagers)

\begin{tabular}{|c|c|c|c|c|c|c|c|c|}
\hline Sl No & $\begin{array}{l}\text { Name of } \\
\text { NTFPs }\end{array}$ & Availability & $\begin{array}{c}\text { Quantity } \\
\text { of product } \\
\text { collected } \\
\text { per year/ } \\
\text { Household }\end{array}$ & $\begin{array}{c}\text { Commercial } \\
\text { importance }\end{array}$ & $\begin{array}{l}\text { Household } \\
\text { importance }\end{array}$ & $\begin{array}{l}\text { Monetary } \\
\text { value of the } \\
\text { product }\end{array}$ & $\begin{array}{l}\text { Multiple } \\
\text { uses of the } \\
\text { product }\end{array}$ & ${ }^{*}$ Grade \\
\hline 1 & Sal (leaf) & 8 months & $\begin{array}{c}>50,000 \\
\text { plates }\end{array}$ & $\sqrt{ }$ & $\sqrt{ }$ & $\begin{array}{l}\text { Rs. } 70 / 1,000 \\
\text { plates }\end{array}$ & $\sqrt{ }$ & 5 \\
\hline 2 & Firewood & Whole year & $>2,000 \mathrm{~kg}$ & $\sqrt{ }$ & $\checkmark$ & Rs. $1.5 / \mathrm{kg}$ & $\sqrt{ }$ & 5 \\
\hline 3 & $\begin{array}{c}\text { Mahua } \\
\text { (flower) }\end{array}$ & 2 months & $20 \mathrm{~kg}$ & $\sqrt{ }$ & $\checkmark$ & Rs. $5 / \mathrm{kg}$ & $\sqrt{ }$ & 5 \\
\hline 4 & Bel (fruit) & 2 months & $30 \mathrm{~kg}$ & $\checkmark$ & $\checkmark$ & Rs. $5 / \mathrm{kg}$ & $\sqrt{ }$ & 5 \\
\hline 5 & Mushroom & 4 months & $25 \mathrm{~kg}$ & $\checkmark$ & $\checkmark$ & Rs. $10 / \mathrm{kg}$ & & 4 \\
\hline 6 & $\begin{array}{c}\text { Kalmegh } \\
\text { (leaf) }\end{array}$ & 3 months & $20 \mathrm{~kg}$ & $\sqrt{ }$ & $\checkmark$ & Rs. $2 / \mathrm{kg}$ & & 4 \\
\hline 7 & Kend (leaf) & 2 months & $\begin{array}{l}20 \text { Chata } \\
\text { (Bundle) }\end{array}$ & $\sqrt{ }$ & $\checkmark$ & Rs. $20 /$ Chata & & 4 \\
\hline 8 & Kend (fruit) & 1 month & $10 \mathrm{~kg}$ & $\sqrt{ }$ & $\checkmark$ & Rs. $10 / \mathrm{kg}$ & & 4 \\
\hline 9 & Jam (fruit) & 1 months & $10 \mathrm{~kg}$ & $\checkmark$ & $\checkmark$ & Rs. $10 / \mathrm{kg}$ & & 4 \\
\hline 10 & Lodh (bark) & 2 months & $20 \mathrm{~kg}$ & v & & Rs. $2 / \mathrm{kg}$ & & 3 \\
\hline
\end{tabular}


Table 3. The ten most important NTFPs in the Jamboni range of the West Midnapur district (ranked by forest villagers)

\begin{tabular}{|c|c|c|c|c|c|c|c|c|}
\hline SI No & $\begin{array}{l}\text { Name of } \\
\text { NTFPs }\end{array}$ & Availability & $\begin{array}{l}\text { Quantity } \\
\text { of product } \\
\text { collected } \\
\text { per year/ } \\
\text { Household }\end{array}$ & $\begin{array}{l}\text { Commercial } \\
\text { importance }\end{array}$ & $\begin{array}{l}\text { Household } \\
\text { importance }\end{array}$ & $\begin{array}{l}\text { Monetary } \\
\text { value of the } \\
\text { product }\end{array}$ & $\begin{array}{l}\text { Multiple } \\
\text { uses of the } \\
\text { product }\end{array}$ & *Grade \\
\hline 1 & Sal leaf & 8 months & $\begin{array}{c}>100,000 \\
\text { plates }\end{array}$ & $\checkmark$ & $\checkmark$ & $\begin{array}{c}\text { Rs. } 60 / \\
1,000 \text { plates }\end{array}$ & $\checkmark$ & 5 \\
\hline 2 & $\begin{array}{l}\text { Mahua } \\
\text { flower }\end{array}$ & 2 months & $20 \mathrm{~kg}$ & $\checkmark$ & $\checkmark$ & Rs. $10 / \mathrm{kg}$ & $\checkmark$ & 5 \\
\hline 3 & Kend leaf & 3 months & $\begin{array}{l}20 \text { Chata } \\
\text { (Bundle) }\end{array}$ & $\checkmark$ & $\checkmark$ & $\begin{array}{l}\text { Rs. 30/ } \\
\text { Chata }\end{array}$ & & 4 \\
\hline 4 & Mush-room & 3 months & $50 \mathrm{~kg}$ & $\checkmark$ & $\checkmark$ & Rs. $10 / \mathrm{kg}$ & & 4 \\
\hline 5 & Sal seed & 2 months & $100 \mathrm{~kg}$ & $\checkmark$ & $\checkmark$ & Rs. $5 / \mathrm{kg}$ & & 4 \\
\hline 6 & Mahua fruit & 1 month & $10 \mathrm{~kg}$ & $\checkmark$ & $\checkmark$ & Rs. $10 / \mathrm{kg}$ & & 4 \\
\hline 7 & Fire-wood & Whole year & $2,000 \mathrm{~kg}$ & & $\checkmark$ & & & 3 \\
\hline 8 & Piyal fruit & 1 month & $5 \mathrm{~kg}$ & $\checkmark$ & $\checkmark$ & Rs. $6 / \mathrm{kg}$ & & 3 \\
\hline 9 & Sal gum & Whole year & $1 \mathrm{~kg}$ & $\checkmark$ & $\checkmark$ & Rs. $80 / \mathrm{kg}$ & & 3 \\
\hline 10 & Bhela fruit & 2 months & $3 \mathrm{~kg}$ & & $\checkmark$ & & & 2 \\
\hline
\end{tabular}

The establishment of micro level or cottage industries could be important in helping forest dwellers to improve their socio-economic conditions, but there are several problems which hinder the exploration of marketing systems for NTFP based value-added products. These include problems raising the initial investment, fluctuating market demand, storage limitations, a lack of modern technical knowledge, poor transportation system and illiteracy (Tewari and Campbell, 1995).

“... small scale enterprises also face some common constraints, including limited access to institutional finance and a lack of tax incentives, highly risky market environments and incomesharing problems. Moreover, as NTFP markets expand and efforts are made to increase local processing capacity in order to capture the value-added benefits, traditional patterns of management, income distribution and the division of labor can become disrupted" (FAO, 1991a and 1991b in Tewari and Campbell, 1995, p. 56).

With these problems in mind, it is important to find solutions that can enhance the marketing opportunities for these value-added products. 


\section{CONCLUSION}

From the research findings it can be said that the poor socio-economic conditions of the forest fringe dwellers are the main reasons for the decline of the tropical dry-deciduous forest cover of these three districts. A micro finance system which incorporates small and medium sized enterprises, based on systematic and scientific harvesting of NTFPs and the increasing manufacture of secondary products from NTFPs may create the opportunity for the forest-dwelling villagers to improve their poor present-day economic conditions. As the market price of value-added products from raw NTFPs is usually higher, the forest dwellers will be able to improve their economic status and simultaneously their dependence on the native forest will be reduced. The target of the West Bengal state Forest Department is to facilitate forest dwellers economically by involving them in a forest-product based microfinance system. Once these economically deprived communities become capable of standing on their own feet they will move outside the forest for alternative sources of income that are more lucrative and less laborious.

After independence, one of the significant initiatives of the Ministry of Forest and Environment, Government of India was to set up National Afforestation and Eco-development Board (NAEB), which works with state Forest Departments all over India, to inspire forest fringe dwellers to take part in Joint Forest Management (JFM) . For the selection of correct species of plants which can produce multiple numbers of NTFPs and are suitable of fitting in with the native environment, the NAEB has played an important role along with the state Forest Departments and JFM members so far.

In general, forest fringe villagers are either marginal farmers or landless agricultural wage laborers. Due to the unfertile barren land cover and a lack of irrigation infrastructure, agricultural activities could not developed in the Purulia, Bankura and West Midnapur districts of West Bengal. A considerable amount of monthly income is therefore generated from the harvesting of NTFPs from the nearest forests. As the raw NTFPs do not sell for a high price, the value-addition or the manufacturing of secondary products from the raw NTFPs is essential if villagers are to improve their present fiscal status.

The JFM process is based on a profit-sharing mechanism whereby forest villagers, who are members of JFM committees, take part in tree plantation

5 FM - In JFM, forest dwellers help the Forest Department by planting new trees and with scheduled felling. In return, forest dwellers get permission to collect minor forest products (NTFPs) for food, fuel, fodder, etc. Forest dwellers can also harvest a certain amount of NTFPs, without damaging the resource base, to sell at local markets to earn their livelihoods. 
and felling organized by the state Forest Department and in return are paid as wage laborers. JFM members also protect the forest cover from illegal felling and smuggling of forest products. For doing this they are allowed to harvest a certain amount of NTFPs for commercial purposes and to fulfil their daily domestic needs, which include food, fodder and firewood.

The formal and informal relationships between the Forest Department staff and JFM members help to reveal indigenous knowledge about forest management. Information about the uses of forest products in tribal sociocultural life (including their ritual and medicinal uses) helps forest officers to enrich the knowledge base regarding forest species and products available from native forests. Through such meetings the Forest Department can discover which artefacts are based on the NTFPs available from the native forests. The production and marketing of such handicraft products in a formal way, with the intervention of government authorized bodies, could serve to enhance the financial status of these underprivileged forest fringe communities. Simultaneously, the intention to more sustainably harvest forest products would strengthen. The manufacturing of value-added products (particularly handicraft products) using indigenous knowledge has enormous potential for supporting sustainable livelihoods. The indigenous knowledge of tribal communities - which are historically related to Indian traditions as a whole - is very much apparent in these handicraft products. Such kinds of products not only enrich our knowledge about forest-based traditional Indian culture but also reveal the historic evolution of Indian art and crafts over time.

\section{REFERENCES}

BELCHER，B.-RUÍZ-PÉREZ，M.-ACHDIAWAN，R., 2005, "Global patterns and trends in the use and management of commercial NTFPs: Implications for livelihoods and conservation", World Development Vol. 33, No. 9, pp. 14351452.

BÜRGI, M.,1999, "A case study of forest change in the Swiss lowlands", Landscape Ecology Vol. 14, No. 6, pp. 567-576.

BYRON, N. - ARNOLD, M., 1999, "What Futures for the People of the Tropical Forests?", World Development Vol. 27, No. 5, pp. 789-805.

CAMPBELL, J. Y. \& TEWARI, D. D., 1995, "Increased development of non-timber forest products in India: Some issues and concerns", Journal of Sustainable Forestry Vol. 3, No. 1, pp. 53-79.

CHANDRASEKHARAN, C., 1998, "Role of Non-Wood Forest Products in Sustainable Forest Management”, Dehra Dun, SEANN Workshop. 
CHOWDHURI, M. K. - CHAKRABORTY, S. M. - MUKHERJEE, A. K., 1992, "Utilisation of Forest Produces - A Study among Forest Dwellers", Bulletin of the Cultural Research Institute Vol. XV1l1, No. 1-2, pp. 44-47.

CHUN-LIN, L. - FOX, J. - XING, L. - LIHONG, G. - KUI, C. - JIERU, W.,1999, "State Policies, Markets, Land-use Practices, and Common Property: Fifty Years of Change in a Yunnan Village, China", Mountain Research and Development Vol. 19, No. 2, pp. 133-139.

CORBRIDGE, S. - KUMAR, S., 2002, "Community, corruption, landscape: tales from the tree trade", Political Geography Vol. 21, pp. 765-788.

CORBRIDGE, S. - JEWITT, S. - KUMAR, S., 2004, Jharkhand: Environment, Development, Ethnicity, New Delhi, Oxford University Press.

DEPARTMENT OF FOREST, G. O. W. B., 2004, State Forest Report West Bengal 2003-2004. DIRECTORATE OF FORESTS, Office of the Principal Chief Conservator of Forest, Kolkata.

DEPARTMENT OF FOREST, G. O. W. B., 2005a, Medicinal Plant Resources of South West Bengal, Research Wing, Department of Forest, Government of West Bengal, Kolkata.

DEPARTMENT OF FOREST, G. O. W. B., 2005b, State Forest Report West Bengal 2004-2005, Directorate of Forest, Office of the Principal Chief Conservator of Forest, Kolkata.

DEVELOPMENT AND PLANNING DEPARTMENT, G. O. W. B., 2007, District Human Development Report Bankura, HDRCC, Development and Planning Department, Government of West Bengal, Kolkata.

EMERY, M. R., 1998, Social Values of Specialty Forest Products to Rural Communities. North American Conference on Enterprise Development Through Agroforestry: Farming the Agroforest for Specialty Products, Centre for Integrated Natural Resources and Agriculture Management (CINRAM), Minneapolis, USA.

GADGIL, M. - VARTAK, V. D., 1975, "Sacred groves of India - A plea for continued conservation”, JBNHS Vol. 72, No. 2, pp. 198-205.

GUNATILAKE, H. M., 1998, "The role of rural development in protecting tropical rainforests: evidence from Sri Lanka", Journal of Environmental Management Vol. 53, No. 3, pp. 273-292.

HAMMETT, A. L., 1999, Special Forest Products: Identifying Opportunities for Sustainable Forest-based Development, Virginia Forest Landowner Update, Virginia Tech, Blacksburg, Virginia.

JEWITT, S., 2002, Environment, Knowledge and Gender: Local Development in India's Jharkhand, Aldershot, Ashgate Publishing Company (SOAS Development Geography Series).

JODHA, N. S.,1990, "Rural common property resources: contributions and crisis", Economic and political weekly, Quarterly review of agriculture Vol. 25, No. 26, pp. A65-A78.

KERR, K. (1991), "The economic potential of handicrafts enterprises in rural development: Focus on Indonesia", Unasylva Vol. 42, No. 165, pp. 31-36.

MAHAPATRA, A. K. \& TEWARI, D. D.,2005, "Importance of non-timber forest 
products in the economic valuation of dry deciduous forests of India", Forest Policy and Economics Vol.7, No. 3, pp. 455-467.

MALHOTRA, K. C., 1993, "Role of Non-Timber Forest Produce in Village Economies in South West Bengal, India", RDFN Vol. 15d, No.1.

MALHOTRA, K. C. - DEB, D. - DUTTA, M. - VASULU, T. S. - YADAV, G. ADHIKARI, M., 1998, "Role of non-timber forest product (NTFP) in village economy", in: CHATTERJEE, M. - YADAV, G. - ROY, S. B. - MUKHERJEE, R. (Eds.) Policy to Practice of Joint Forest Management, New Delhi, Inter-India Publications.

MALLIK, R. M., 2000, "Sustainable Management of Non-Timber Forest Products in Orissa: Some Issues and Options", Indian Journal of Agricultural Economics Vol. 55, No.3, pp. 385-396.

MENDELSOHN, R., 1994, "Property Rights and Tropical Deforestation", Oxford Economic Papers Vol. 46, pp. 750-756.

MICHAEL ARNOLD, J. E. - RUIZ-PEREZ, M., 2005, "Can non-timber forest products match tropical forest conservation and development objectives?", in: SAYER, J. (ed.) The Earthscan Readers in Forestry and Development, London, Earthscan.

MYERS, N., 1988, “Tropical Forests: Much More Than Stocks of Wood", Journal of Tropical Ecology Vol. 4, No. 2, pp. 209-221.

OLSSON, G.,1991, "The socio-economic importance of non-timber forest products in the South Pacific: Focus on Vanuatu", Unasylva Vol. 42, No. 165, pp. 24-30.

PETERS, C. M. - GENTRY, A. H. - MENDELSOHN, R. O. (1989), "Valuation of an Amazonian rainforest", Nature Vol. 339, No. 6227, pp. 655-656.

PFUND, J. - L. - ROBINSON, P. (2005), Non-Timber Forest Products between Poverty Alleviation and Market Forces, Berne, Switzerland, Inter Cooperation.

PULIDO, M. T. - CABALLERO, J. (2006), "The impact of shifting agriculture on the availability of non-timber forest products: the example of Sabal yapa in the Maya lowlands of Mexico", Forest Ecology and Management Vol. 222, No. 1-3, pp. 399-409.

PUTZ, F. E. - BLATE, G. M. - REDFORD, K. H. - FIMBEL, R. - ROBINSON, J.,2001, "Tropical Forest Management and Conservation of Biodiversity: An Overview", Conservation Biology Vol. 15, No. 1, pp. 7-20.

RIBBENTROP, B., 1900, Forestry in British India, Office of the Superintendent of Government Printing, Calcutta (Kolkata).

ROY, S. B. (ed.), 2003, Contemporary studies in natural resource management in India, New Delhi, Inter-India Publications.

SALISBURY, D. S., 2002, Geography in the Jungle: Investigating the Utility of Local Knowledge for Natural Resource Management in the Western Amazon. Department of Geography, University of Florida, Gainesville, Florida.

SINGH, M. K. - ARDEY, J., 2003, "Study of the extraction, processing and local trade of non-timber forest products in relation to the socio-economic uplift of the local communities under the Joint Forest Management system - A case study of village Jabalpur in Dewas and Chandermuli in Jhabua district in India", in: ROY, S. B. 
(Ed.) Contemporary studies in natural resource management in India, New Delhi, Inter-India Publications.

STEINBERG, M. K.,1998, "Political Ecology and Cultural Change: Impacts on Swidden-fallow Agroforestry Practices among the Mopan Maya in Southern Belize", The Professional Geographer Vol. 50, No. 4, pp. 407-417.

TAYLOR, P.J., 1971, "Distance transformation and distance decay function", Geographical Analysis Vol. 3, pp. 221-238.

TORRAS, M., 2000, "The total economic value of Amazonian deforestation, 19781993", Ecological Economic Vol. 33, No. 2, pp. 283-297.

TURNER, N. J., 2001, “"Keeping it Living”: Applications and Relevance of Traditional Plant Management in British Columbia to Sustainable Harvesting of Non-timber Forest Products", United States Dept. of Agriculture Forest Service General Technical Report, No. 217, pp. 66-77.

WBFDC, 2006, 32nd Annual Report 2005-2006. West Bengal Forest Development Corporation Limited, Government of West Bengal, Kolkata.

WILKINSON, K. M. - ELEVITCH, C. R., 2000, Non-timber Forest Products Part II: Introduction to Planning a NTFP Enterprise, Agroforestry Guides for Pacific Islands, Permanent Agriculture Resources, Holualoa, Hawaii.

YADAV, G. - ROY, S. B., 1991, Significance of non-timber forest produces (NTFPS): Availability and its utilisation pattern in rural community of Midnapur, West Bengal. 